\title{
ANNUAL OF NAVIGATION 20/2013
}

VERSITA

DOI: 10.2478/aon-2013-0007

BYUNG-HYUN LEE, GYU-IN JEE

Konkuk University, Republic of Korea

\section{PERFORMANCE ANALYSIS \\ OF DOPPLER AIDED GPS/QZSS \\ PRECISE POSITIONING FOR LAND VEHICLES}

\begin{abstract}
For ITS (Intelligent Transport Systems), especially for land vehicles, precise position is the prime information. GNSS is the most popular navigation system. Generally, ITS demands lane distinguishable positioning accuracy. However urban area is most environments of land vehicles and the signal blocks of satellite with low elevation angle, multipath error and etc. make unreliable positioning results. Especially, lack of number of visible satellites (fewer than 4 satellites) cannot provide positioning results.

QZSS (Quasi-Zenith Satellite System) which operated by Japan has high interoperability. In addition, its elevation angle is very high in long time in Korea. It means QZSS signal can be received in urban area and it can be great advantage for land vehicles.

The most positioning errors are occurred by multipath, cycle slip, and etc. For example, multipath error is unexpected momentary error. In order to reduce position error, smoothing technique in position domain is needed.

In this paper, precise positioning for land vehicles was evaluated. First, by using QZSS, probability of navigation solution was enhanced. Second, the reliability is improved by smoothing positioning result using Doppler measurement. The analysis was performed by trajectory analysis using precise map data.
\end{abstract}

Keywords:

QZSS, land navigation, Intelligent Transport Systems.

\section{INTRODUCTION}

In order to get highly precise position in GNSS system, carrier phase measurements must be used. As known in [4], the resolution of carrier phase is typically better 
than $0.1 \mathrm{~mm}$. However, so as to use this measurement, unknown integer cycles of carrier phase should be resolved. This unknown number is so called integer phase ambiguity.

In the open sky environment, ambiguity can be resolved and satellites are in line-of-sight well. But in urban case, there are many problems. First, integer ambiguity is rarely resolved. Most land vehicles drive in urban area, and there're many tall buildings. These cause severance of phase lock loop, and it appears as cycle slip. To use carrier phase measurement stably, successive phase tracking should be guaranteed. Second is multipath. Carrier phase measurements are robust to multipath. However code measurements have large multipath error and it is reflected to position error. But Doppler measurement has small influence by multipath than code measurements and is free from integer ambiguity. Thus, Doppler is one of the necessary measurements for urban precise positioning.

If multipath and cycle slips are detected and exclude correspondent satellite signals, the lack of visible satellites make positioning impossible. In order to solve this problem, Japan planned to operate QZSS and now one satellite is operating. The purpose of QZSS is to enhance availability with high elevation satellite.

In this paper, position smoothing filter using Doppler measurements was implemented to enhance positioning accuracy and QZSS was used to improve availability.

\section{BENEFITS OF DOPPLER MEASUREMENTS AND POSITION SMOOTHING FILTER}

Conventional RTK uses code and carrier phase measurements for precise positioning. Precise positioning is for survey land until now, so it is used in open sky environment. And for precise positioning, integer ambiguity should be resolved. It means navigation filter needs successive phase measurements. However urban area has frequent variation of visible satellites by surroundings, so it is hard to measure phase measurements continuously. Thus fixed solution is rarely calculated in urban. It means conventional RTK is not practical solution in urban environment. In this paper, Doppler measurements are used for more robust and precise float solution.

Typically, users are moving vehicles in urban. So velocity is one of the important information. Taken together, we need reliable single-epoch measurements 
and that enhances performance of velocity estimation. And Doppler measurements are the meaning of amount of change. The equation is as below.

$$
\lambda f_{u}^{i}=\dot{r}_{u}^{i}+\left(\dot{B}_{u}-\dot{B}^{i}\right)+\dot{I}_{u}^{i}+\dot{T}_{u}^{i}+\delta \dot{V}^{i}+\varepsilon,
$$

where:

$\lambda$ - wavelength;

$f_{u}^{i}$ - raw Doppler measurements of receiver u from satellite $I$;

$\dot{r} \quad$ - geometric range rate;

$\dot{B}_{u}$ - receiver clock drift;

$\dot{B}^{i}$ - satellite clock drift;

$\dot{I}_{u}^{i} \quad$ - ionospheric delay rate;

$\dot{T}_{u}^{i}$ - tropospheric delay rate;

$\delta \dot{V}^{i}$ - calculation error of satellite velocity;

$\varepsilon \quad$ - receiver noise.

And the physical expression is defined in equation (2).

$$
\lambda f_{u}^{i}=\boldsymbol{h}_{u}^{i} \cdot\left(\boldsymbol{v}_{u}-\boldsymbol{V}^{i}\right)+\dot{B}_{u}+\xi,
$$

where:

$\boldsymbol{h}_{u}^{i}$ - LOS(line-of-sight) vector;

$\boldsymbol{v}_{u}$ - receiver velocity;

$\boldsymbol{V}^{i}$ - satellite velocity;

$\xi-$ ionospheric, tropospheric delay rate, velocity error of satellite and receiver noise.

That is, Doppler measurements are direct measurements for velocity, and Doppler added navigation filter can improve performance of velocity estimation [3] and more accurate velocity makes state prediction improved.

And position smoothing filter [5] using Doppler measurement can reduce position error in urban area (Figure 1). This smoothing filter use delta-position estimation. 


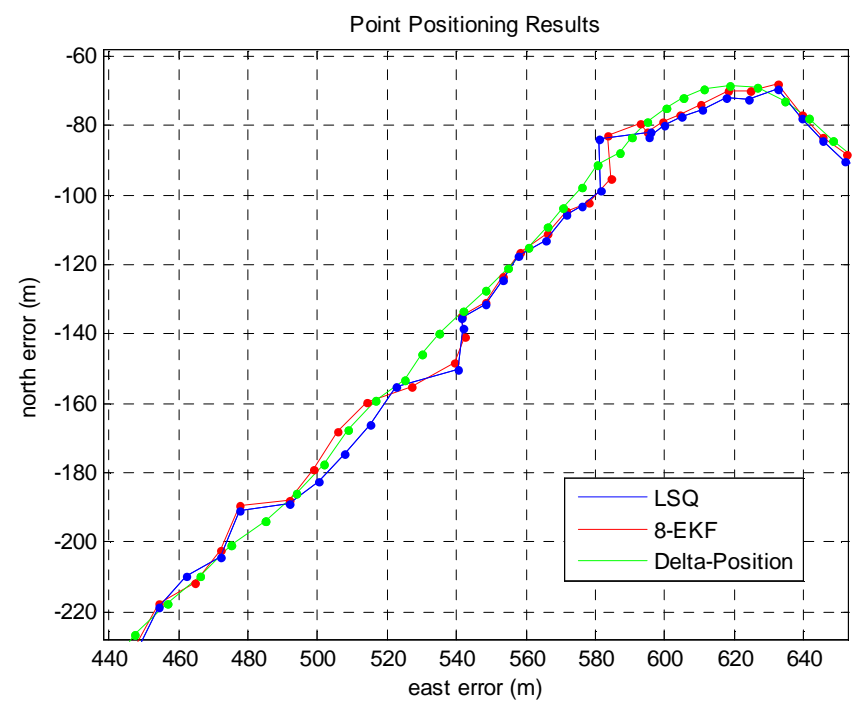

Fig. 1. Position smoothing filter in Standalone GPS [own study]

In Ref. [5], delta-position was estimated by integrating Doppler measurements in order to make noise level lower. The inputs of position smoothing filter are solution of navigation filter and delta-position and position smoothing filter is kind of fusion filter. This fusion filter gives smoothing effect in position domain.

Equation (3) shows double differenced Doppler measurements

$$
\dot{\rho}_{i, j}^{k, l}=\left(h_{i, j}^{k} v^{k}-h_{i, j}^{l} v^{l}\right)+h_{j}^{k, l} v_{j}
$$

And equation (4) represents the term of user velocity of equation (3)

$$
h_{j}^{k, l} v_{j}=\dot{\rho}_{i, j}^{k, l}-\left(h_{i, j}^{k} v^{k}-h_{i, j}^{l} v^{l}\right) .
$$

The left term of equation (4) means delta-position. That is, delta-position can be estimated using double differenced Doppler measurements directly. And errors of satellite and receiver are eliminated or reduced because it is double differenced. Thus Doppler measurements of single-epoch can provide reliable delta-position.

\section{QZSS (QUASI-ZENITH SATELLITE SYSTEM)}

The MICHIBIKI which is the first QZSS satellite has lemniscate orbit. Figure 2 shows QZSS satellite ground track. 


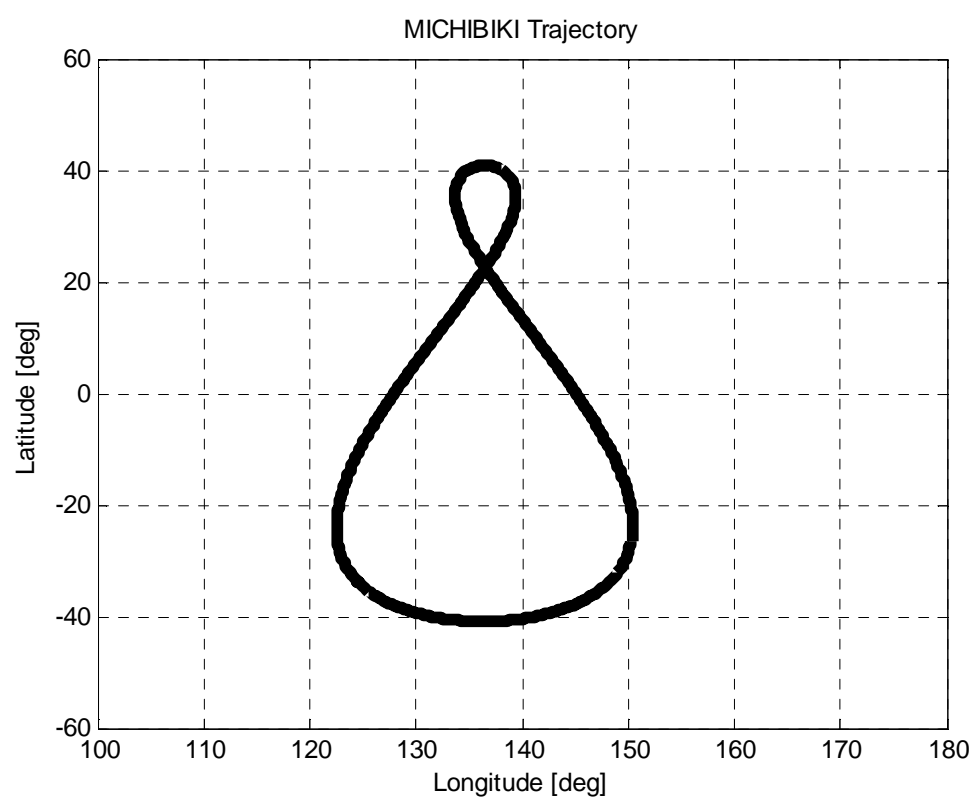

Fig. 2. QZSS Satellite Ground Track [own study]

Each satellite systems in general have different coordinate and time system, however QZSS is designed for interoperation with GPS. Thus QZSS doesn't need any other technique to assign time system with GPS. The coordinate system of QZSS is defined to International Terrestrial Reference System, thus the difference from GPS is less than $0.02 \mathrm{~m}$ [6].

\section{EXPERIMENTAL RESULTS}

The performance of Doppler aided GPS/QZSS navigation system was evaluated by applying to RTK. Figure 3 shows the outline of navigation System of in this paper. 


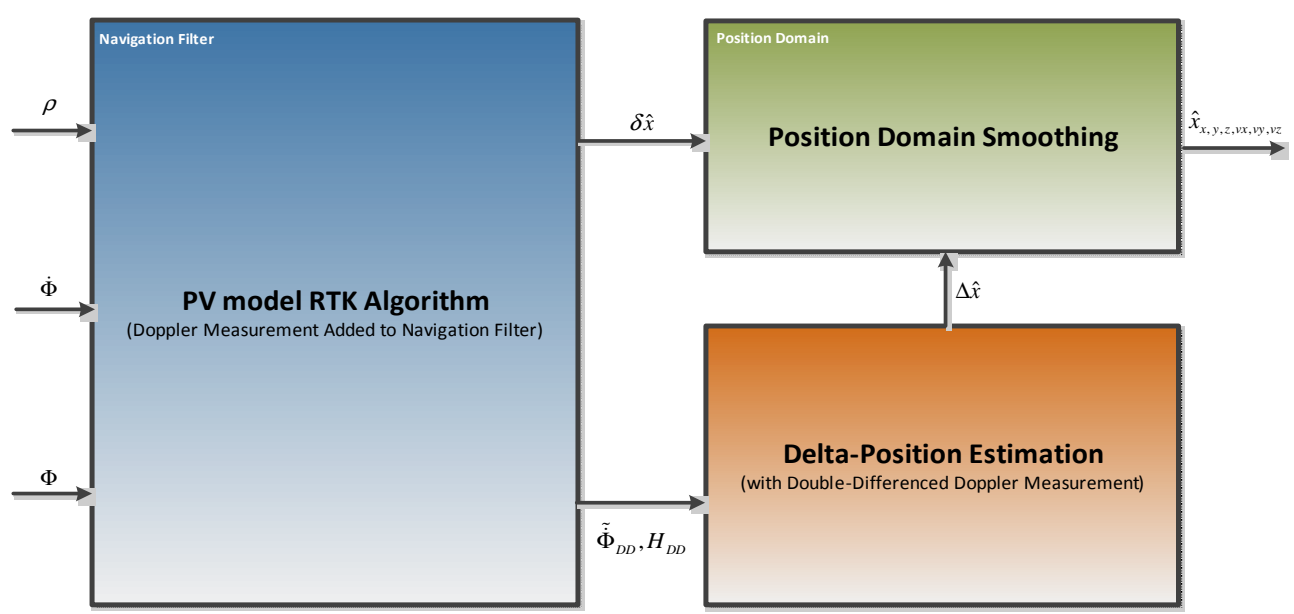

Fig. 3. Outline of Navigation System [own study]

In order to evaluate system performance, experiment was performed in urban area which has precise map data. And the performance was analyzed by trajectory comparison. Figure 4 shows the environment and precise map data. In Figure 4, the magenta refers centerline.
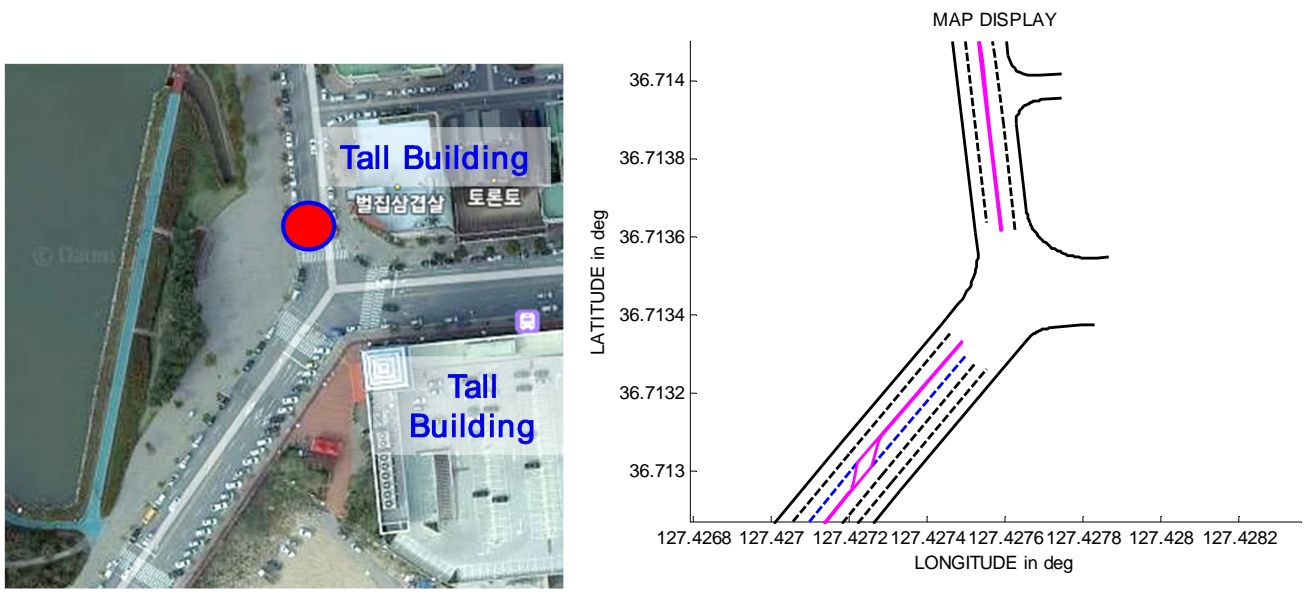

Fig. 4. Test site and Precise map data [own study]

Table 1. Experiment environment [own study]

\begin{tabular}{|c|c|}
\hline Date & $2012 / 04 / 13$ \\
\hline \multirow{2}{*}{ Receiver } & Reference: Novatel Flexpak6 \\
\cline { 2 - 2 } & Rover: Novatel Flexpak6 \\
\hline Baseline & km \\
\hline Performance Analysis & $\begin{array}{c}\text { Precise Map Data } \\
\text { Driving 3 times in same lane }\end{array}$ \\
\hline
\end{tabular}


In this experiment, the true trajectory is the first lane and driven 3 times in same lane.

Figure 5, 6 shows GPS only results. In good situation, the arrangement of satellites is good and enough to calculate position although cycle slip is detected in PRN 27(this signal is excluded in process). And because of PRN 2, DOP is good (HDOP: 1.505). But in bad situation, the signals of PRN 9 and 27 exceeded the threshold of fault detection, thus these are excluded. So it's enough to calculate position, however the DOP is bad (HDOP: 6.84). But the result of position smoothing filter shows better positioning performance.

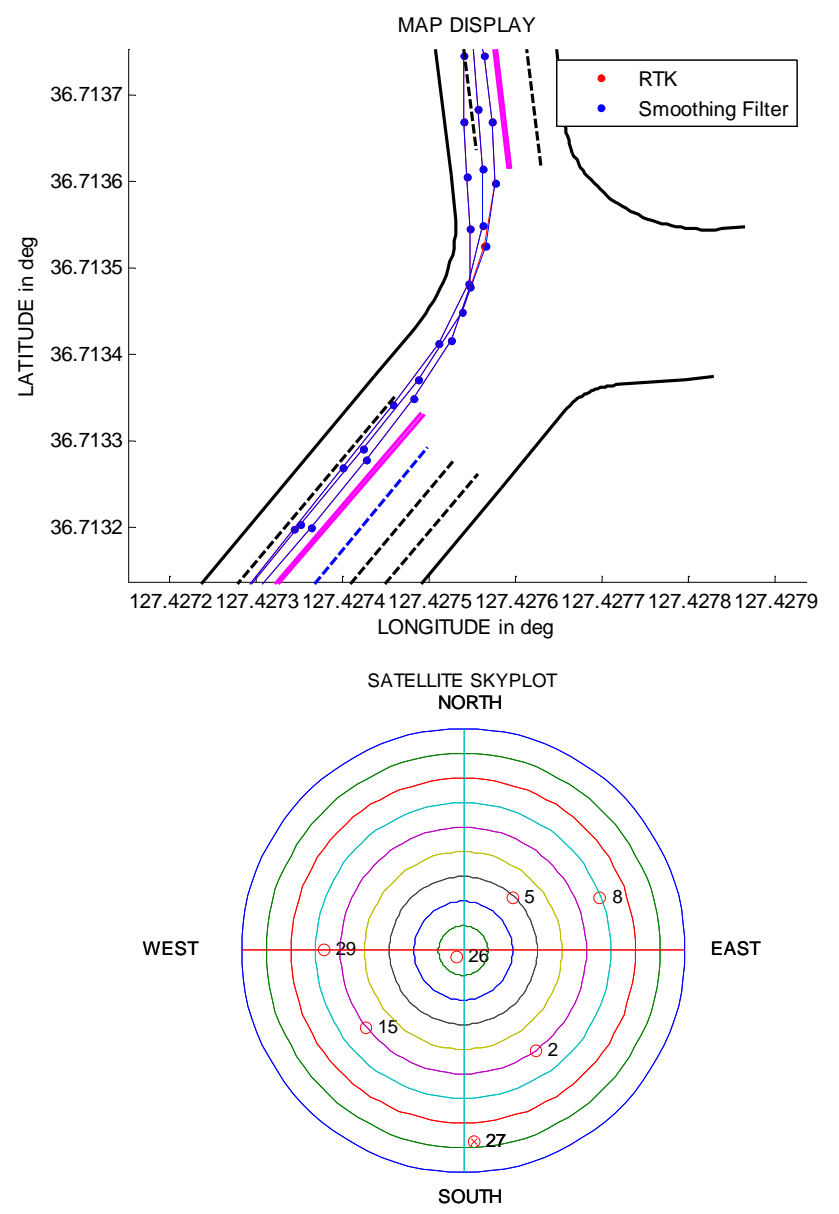

Fig. 5. GPS Only (Good situation, PRN27 excluded) [own study] 


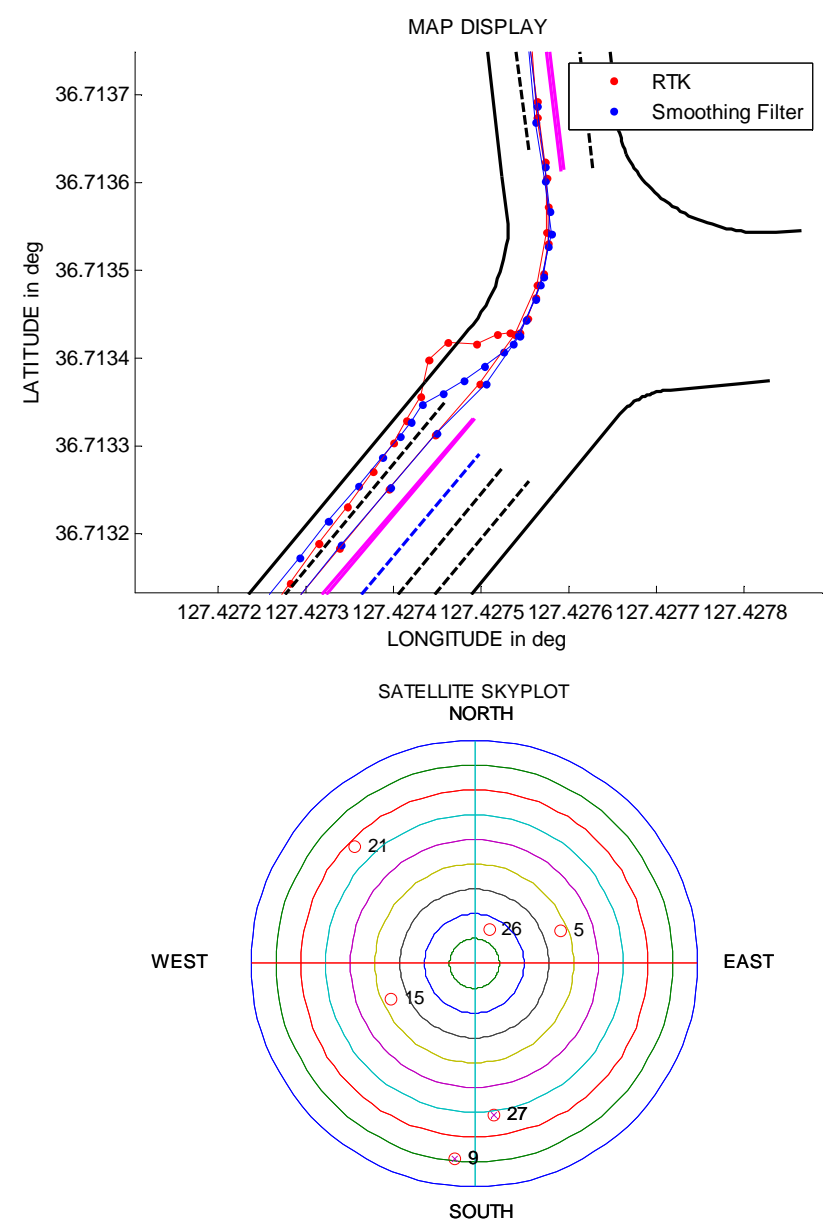

Fig. 6. GPS Only (Bad situation, PRN 9, 27 excluded) [own study]

Figure 7 shows GPS/QZSS combined results. On the contrary to GPS only, the positioning accuracy is as much as lane distinguishable. In this situation, there are only 3 GPS signals can use. However positioning is available by one additional QZSS, and DOP (HDOP: 1.564) is much better too. Table 2 refers epochs of fewer than 4 satellites in this bad case. This shows only one satellite with high elevation angle can provide much more availability. 


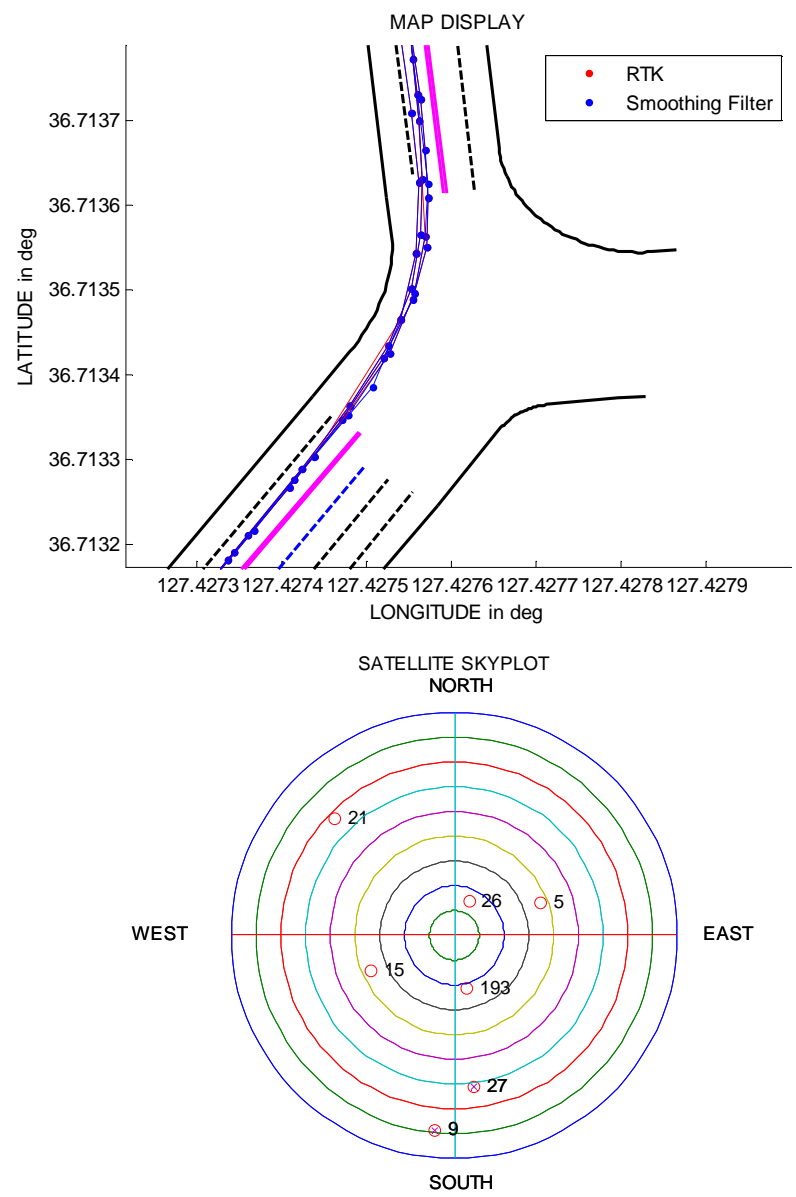

Fig. 7. GPS/QZSS Only (Bad situation, PRN 9, 27 excluded) [own study]

Table 2. Epochs of fewer than 4 satellites [own study]

\begin{tabular}{|c|c|c|}
\hline Total: 400 epoch & GPS only & GPS/QZSS \\
\hline No Fault Detection & 54 & 24 \\
\hline Fault Detection(Exclusion) & 58 & 28 \\
\hline
\end{tabular}

Table 3. Summary of HDOP in bad situation [own study]

\begin{tabular}{|c|c|c|}
\hline & GPS only & GPS/QZSS \\
\hline HDOP & 6.84 & 1.564 \\
\hline
\end{tabular}




\section{CONCLUSIONS}

The conventional RTK cannot be a practical solution in urban area because it is hard to resolve integer ambiguity. In addition, the positioning error by multipath and cycle slips is significant problem too. If the polluted signals are excluded then there might be fewer than 4 satellites. In this paper, in order to improve positioning accuracy and availability in urban, position smoothing filter and additional satellite system, QZSS, were used. QZSS which is one additional satellite signal can much more improve availability, and the position smoothing filter can improve too. It means this implemented system can provide more available positioning results.

\section{Acknowledgments}

This research was supported by a grant from Transportation System Innovation Program (TSIP) funded by Ministry of Land, Transport and Maritime Affairs (MLTM) of Korean government.

\section{REFERENCES}

[1] Adeniyi Iyiade, Real Time Kinematic GPS in an Urban Canyon Environment, Map Asia Conference, 2005.

[2] Byung-Hyun Lee, Gyu-In Jee, Performance Analysis of GPS-RTK Floating Solution with Doppler Measurement, IS-GPS/GNSS 2010, Taipei.

[3] Byung-Hyun Lee, Sung-Hyuck Im, Gyu-In Jee, Performance Analysis of GPS Standalone using Carrier-smoothed Doppler Measurement, GNSS Workshop, 2010, Jeju.

[4] Hofmann-Wellenhof, Lichtenegger, Wasle, GNSS - Global Navigation Satellite Systems, GPS, GLONASS, Galileo \& More, Springer, Wien New York 2008.

[5] Leppakoski H., Syrjarinne J., Takala J., Complementary Kalman Filter for Smoothing GPS Position with GPS Velocity, ION GPS/GNSS 2003, Portland, OR.

[6] Quasi-Zenith Satellite System Navigation Service Interface Specifications for QZSS (IS-QZSS Ver.1.3). 
[7] Serrano L., Kim D., Langley R. B., A Single GPS Receiver as a Real-Time, Accurate Velocity and Acceleration Sensor, ION GNSS 17th ITM, 21-24 Sept. 2004, Long Beach, CA.

Received April 2012

Reviewed January 2013

\section{BYUNG-HYUN LEE}

Konkuk University,

Republic of Korea

e-mail: maximan@konkuk.ac.kr

GYU-IN JEE

Konkuk University,

Republic of Korea

e-mail: gijee@konkuk.ac.kr

\section{STRESZCZENIE}

Dla inteligentnych systemów transportowych, zwłaszcza w odniesieniu do pojazdów lądowych, dokładna informacja o pozycji jest pierwszorzędna. Systemy satelitarne (GNSS) to obecnie najbardziej popularne systemy nawigacyjne. Zasadniczo inteligentne systemy transportowe wymagają znajomości pozycji determinowanej warunkami drogowymi, a obszary miejskie stanowią środowisko, w którym porusza się największa liczba pojazdów lądowych. Takie ograniczenia, jak przesłanianie niskich satelitów, błąd wielodrożności i tym podobne powodują, że pozycje wyznaczane metodami satelitarnymi stają się mało wiarygodne. Brak wyznaczeń może być spowodowany zwłaszcza brakiem dostatecznej liczby widocznych satelitów (mniej niż cztery).

QZSS (Quasi-Zenitalny System Satelitarny), uruchomiony w Japonii, cechuje się w tym względzie niezwykle korzystnymi cechami. W dodatku jego wysokość topocentryczna przez długi czas jest bardzo duża dla obserwatora znajdującego się w Korei. Oznacza to, że sygnał tego systemu może być odbierany w obszarze miejskim, co stanowi bardzo korzystną cechę dla pojazdów lądowych.

Większość błędów pozycji wynika w tym wypadku z błędu wielodrogowości, przeskoków fazy i tym podobnych. Na przykład, wielodrogowość obrazuje się jako chwilowe, niespodziewane odchylenie pozycji. Dla zmniejszenia tego rodzaju błędów niezbędna jest technika wygładzania pozycji.

W artykule ocenie poddano dokładność pozycjonowania pojazdów lądowych. Po pierwsze poprzez zastosowanie QZSS poprawiono prawdopodobieństwo poprawnego rozwiązania, po 
drugie poprzez zastosowanie technik wygładzania z użyciem pomiarów dopplerowskich poprawiono wiarygodność wyznaczeń. Analizy wyników dokonano przez analizę trajektorii, odnosząc ją do dokładnych danych mapy. 